\title{
Strategi Guru dalam Meningkatkan Kualitas Mengajar selama Masa Pandemi COVID-19
}

\author{
Muhammad Yusuf Siregar1; Suharian Amiril Akbar² \\ UIN Sumatera Utara \\ Manajemen Pendidikan Islam \\ muhammadyusufsiregar0112@gmail.com
}

\begin{abstract}
The purpose of this study was to determine teacher strategies in improving the quality of teaching during the COVID-19 Pandemic. The research was conducted with a descriptive qualitative method using a naturalistic qualitative approach, data were collected through observation and interviews. The subjects are the principal and teacher. The results showed that online learning made it easier for teachers to transfer information in various situations and conditions because online learning was supported by various platforms ranging from discussions to face-to-face virtually. However, this needs to be evaluated and adjusted to local conditions, given the ability of parents to provide different online learning facilities. The key is to maximize the ability of students to learn in a pandemic like this.
\end{abstract}

Keywords: COVID-19, Performance, Online, and Teacher

\begin{abstract}
Abstrak
Tujuan penelitian ini untuk mengetahui strategi guru dalam meningkatkan kualitas mengajar selama masa Pandemi COVID-19. Penelitian dilakukan dengan metode kualitatif deskriptif menggunakan pendekatan kualitatif naturalistik, data dikumpulkan melalui observasi dan wawancara. Subjeknya adalah kepala sekolah dan guru. Hasil penelitian menunjukkan bahwa pembelajaran online memudahkan guru dalam melakukan transfer informasi pada berbagai situasi dan kondisi, karena pembelajaran online didukung oleh berbagai platform mulai dari diskusi hingga tatap muka secara virtual. Namun, hal ini perlu di evaluasi dan disesuaikan dengan kondisi setempat, mengingat kemampuan orang tua memberikan fasilitas pembelajaran online berbeda. Kuncinya adalah memaksimalkan kemampuan peserta didik belajar dalam kondisi pandemic seperti ini.
\end{abstract}

Kata Kunci: COVID-19, Daring, Guru, dan Kinerja 


\section{A. Pendahuluan}

Pandemi COVID-19 secara tiba-tiba mengharuskan elemen pendidikan untuk melakukan Pembelajaran pada Masa Pandemi COVID-19 mempertahankan pembelajaran secara online. Kondisi saat ini mendesak untuk melakukan inovasi dan adaptasi terkait pemanfaatan teknologi yang tersedia untuk mendukung proses pembelajaran. Praktiknya mengharuskan pendidik maupun peserta didik untuk berinteraksi dan melakukan transfer pengetahuan secara online. Pembelajaran online dapat memanfaatkan platform berupa aplikasi, website, jejaring sosial maupun learning management system. Berbagai platform tersebut dapat dimanfaatkan untuk mendukung transfer pengetahuan yang didukung berbagai teknik diskusi dan lainnya.

Pembelajaran online didefinisikan sebagai pengalaman transfer pengetahuan menggunakan video, audio, gambar, komunikasi teks, perangkat lunak dan dengan dukungan jaringan internet (Zhu \& Liu, 2020). Permasalahan mengajar dalam masa pandemi COVID-19 menjadi permasalahan serius di seluruh dunia, termasuk Indonesia. Indonesia juga berusaha untuk mengatasi permasalahan ini sebagai suatu prioritas utama. Semua bentuk kegiatan yang menyebabkan keramaian, kerumunan dan interaksi secara langsung. Termasuk sekolah yang memenuhi kriteria tersebut mulai ditutup oleh pemerintah sejak bulan Maret. Oleh sebab itu, aktivitas di sekolah pun dihentikan dan proses belajar mengajar tidak lagi dilakukan di sekolah melainkan melalui daring di rumah masing-masing, untuk menghindari penyebaran covid-19.

Korban akibat wabah covid-19, tidak hanya pendidikan ditingkat Sekolah Dasar/Madrasah Ibtidaiyah, Sekolah Menengah Pertama/Madrasah Stanawiyah, dan Sekolah Menengah Atas/Madrasah Aliyah, tetapi juga perguruan tinggi. Seluruh jenjang pendidikan dari sekolah dasar/ibtidaiyah sampai perguruan tinggi (universitas) baik yang berada dibawah Kementerian Pendidikan dan Kebudayaan RI maupun yang berada dibawah Kementerian Agama RI semuanya memperoleh dampak negatif karena pelajar, siswa dan mahasiswa "dipaksa" belajar dari rumah karena pembelajaran tatap muka 
ditiadakan untuk mencegah penularan covid-19. Padahal tidak semua pelajar, siswa dan mahasiswa terbiasa belajar melalui Online. Apalagi guru dan dosen masih banyak belum mahir mengajar dengan menggunakan teknologi internet atau media sosial terutama di berbagai daerah.

Berdasarkan uraian tersebut, maka dilakukan review artikel dengan tujuan penelitian untuk memberikan tinjauan umum terkait pembelajaran online pada masa pandemi COVID-19 di SMP IT Al-Hijrah Deli Serdang.

\section{B. Metode}

Penelitian ini menggunakan metode kualitatif yaitu dengan pendekatannya menggunakan metode studi kasus (Jean Rudduck, 1985). Eksplorasi yang digunakan untuk mendapatkan informasi mengenai strategi guru dalam masa pandemi COVID-19 terhadap kegiatan proses belajar mengajar di sekolah menengah pertama di SMP IT Al-Hijrah Deli Serdang. Dalam penelitian ini, responden sebanyak 3 orang guru (Meredith D, 2003). Wawancara semi-terstruktur dilakukan dan daftar pertanyaan disusun untuk wawancara dikembangkan berdasarkan literatur terkait.

\section{Hasil dan Pembahasan}

Kebijakan social distancing maupun physical distancing guna meminimalisir penyebaran COVID-19 mendorong semua elemen pendidikan untuk mengaktifkan kelas meskipun sekolah tutup. Penutupan sekolah menjadi langkah mitigasi paling efektif untuk meminimalisir penyebaran wabah pada anak-anak. Solusi yang diberikan yakni dengan memberlakukan pembelajaran di rumah dengan memanfaatkan berbagai fasilitas penunjang yang mendukung. Selama masa pandemi COVID-19 pembelajaran di rumah atau online menjadi solusi melanjutkan sisa semester.

\section{1) Kendala Pembelajaran Online}

Pembelajaran online sangat berdampak pada guru. Yang pertama, kompetensi guru dalam menggunakan teknologi akan mempengaruhi kualitas program belajar mengajar. Oleh karena itu sebelum diadakan program belajar

online sebaiknya para guru diberikan pelatihan terlebih dahulu. Bagi guru 
muda, mereka menjadi lebih cepat belajar dan menjadi mahir menggunakan teknologi internet atau media sosial sebagai sarana pembelajaran. Namun beberapa guru senior belum sepenuhnya mampu menggunakan perangkat atau fasilitas untuk penunjang kegiatan pembelajaran online dan perlu pendampingan.

Kedua, fasilitas yang mendukung kelnacaran pembelajaran online. Fasilitas ini sangat penting untuk kelancaran proses belajar mengajar khususnya pada pembelajaran online. Seharusnya terlebih dahulu disediakan fasilitas seperti laptop, komputer ataupun handphone yang akan memudahkan guru untuk memberikan materi belajar mengajar secara online. Ketiga, guru belum memiliki budaya belajar jarak jauh. Sebab selama ini sistem belajar dilaksanakan melalui tatap muka. Guru terbiasa terbiasa berada di sekolah untuk berinteraksi dengan murid-murid, dengan adanya metode pembelajaran jarah jauh membuat para guru perlu waktu untuk beradaptasi dan mereka menghadapi perubahan baru yang secara tidak langsung akan mempengaruhi kualitas hasil belajar.

Keempat adalah kejenuhan yang dirasakan oleh guru dengan penutupan sekolah atau libur sekolah yang terlalu panjang. Guru yang dulunya terbiasa berada di sekolah dan berinteraksi dengan sejawat dan muridmuridnya, merasa kehilangan jiwa sosial. Karena jika di sekolah mereka bisa bermain berinteraksi dengan guru-guru lain dan para murid tetapi kali ini mereka tidak biasa dan hanya sendiri dirumah. Kelima adalah kesiapan pendidik dan peserta didik untuk berintereaksi secara online. Infrastruktur yang mendukung pembelajaran online secara gratis melalui berbagai ruang diskusi seperti Google Classroom, Whatsapp, Kelas Cerdas, Zenius, Quipper dan Microsoft. Fitur Whatsapp mencakup Whatsapp Group yang dapat digunakan untuk mengirim pesan teks, gambar, video dan file dalam berbagai format kepada semua anggota (Kusuma \& Hamidah, 2020). 


\section{2) Platform Pembelajaran Online dan Permasalahannya}

Google Clasroom memungkinkan guru untuk mengembangkan pembelajaran kreatif. Diskusi dan transfer pengetahuan secara face-to-face layaknya bertemu melalui beragam platform video teleconference yang banyak tersedia gratis seperti Zoom dan Google Meet. Platform tersebut menjadikan pendidik dan peserta didik untuk bertemu dan berinteraksi secara virtual dengan fasilitas pesan instan dan kegiatan presentasi (Wiranda \& Adri, 2019).

Aktifitas pembelajaran yang dapat dilakukan mulai dari diskusi, presentasi hingga pemberian tugas. Ini selaras dengan penelitian Firman dan Rahayu (2020) bahwa pembelajaran online melatih kemandirian belajar. Ini akan membutuhkan keterlibatan peserta didik yang lebih besar untuk meningkatkan perilaku belajar observasional. Perilaku tersebut dapat dilakukan dengan membaca, memaknai postingan diskusi dan mendiskusikan video atau konten pembelajaran (Zayapragassarazan, 2020).

Adanya wabah Covid-19 memaksa para guru harus menggunakan teknologi, sehingga suka tidak suka dan mau tidak mau harus belajar dan siap mengajar melalui jarak jauh dengan menggunakan teknologi. Setiap sekolah menyiapkan alat dan sistem pembelajaran jarak jauh dan melakukan bimbingan teknis kepada para guru agar bisa menggunakan teknologi moderen dalam pembelajaran untuk meningkatkan kualitas anak didik di sekolah dasar. Kendala yang dihadapi para guru adalah adanya penambahan biaya pembelian kuota internet bertambah, teknologi online memerlukan koneksi jaringan ke internet dan kuota oleh karena itu tingkat penggunaaan kuota internet akan bertambah dan akan menambah beban pengeluaran guru.

Untuk melakukan pembelajaran online selama beberapa bulan tentunya akan diperlukan kuota yang lebih banyak lagi dan secara otomatis akan meningkatkan biaya pembelian kuota internet. Kompetensi guru dalam memanfaatkan teknologi dan menguasai teknologi untuk pembelajaran dituntut untuk meningkat dengan cepat untuk merespon online Home Learning. Komunikasi guru dan sekolah dengan orang tua harus terjalin dengan lancar. Artinya, ada pengeluaran tambahan biaya yang harus dibayar 
oleh guru baik berupa material maupun nonmaterial (Ahmadi, 1995). Misalnya pulsa telpon, pulsa untuk akses internet, dan terutama waktu. Salah satu biaya yang otomatis harus dibayar oleh guru adalah guru juga harus memberi technical support pada orang tua apabila terjadi glitches (masalah) dengan baik yg berhubungan dengan teknologi yang langsung digunakan dalam proses pembelajaran maupun setting gawai yang digunakan oleh peserta didik.

Ini akan membiasakan peserta didik untuk mengumpulkan dan mengelola informasi terkait tugas yang diberikan tanpa batasan ruang dan waktu. Hal ini dikarenakan pembelajaran online memungkinkan akses informasi dan pengetahuan dirumah dan dimanapun yang disesuaikan dengan kenyamanan peserta didik. Belajar online menuntut peran pendidik mengevaluasi efektivitas dan disesuaikan dengan kebutuhan belajar. Ini penting dilakukan untuk tetap memenuhi aspek pembelajaran seperti proses pengetahuan, moral, keterampilan, kecerdasan dan estetika.

\section{3) Komunikasi dalam Pembelajaran Online}

Mengingat bahwa perubahan ke pembelajaran online secara tidak langsung berpengaruh pada daya serap peserta didik. Penting untuk diperhatikan yakni komunikasi orang tua dan pendidik untuk mewujudkan kemandirian belajar peserta didik selama masa pandemic COVID-19. Ragam manfaat yang diperoleh, tentu memiliki kendala yang dirasakan pendidik maupun peserta didik dalam pembelajaran online. Kendala yang dihadapi yakni kondisi wilayah di Indonesia yang beragam menyebabkan tidak semua wilayah terjangkau oleh layanan internet dan sebaran jaringan internet yang lamban sewaktu-waktu (Khasanah et al., 2020).

Pandemi COVID-19 ini mengakibatkan terjadinya perubahan kebijakan secara mendasar dalam dunia pendidikan tanah air. Menteri Pendidikan dan Kebudayaan RI, Nadiem Anwar Makarim telah mengeluarkan beberapa kebijakan untuk mengatur kegiatan pembelaran selama masa pandemi ini. Hal tersebut dikeluarkan melalui Surat edaran Nomor 4 Tahun 2020, yaitu tentang 
Pelaksanaan Kebijakan Pendidikan dalam Masa Darurat Penyebaran Coronavirus Disease (COVID-19), tertanggal 24 Maret 2020.

Secara positif pembelajaran ini sangat membantu keberlangsungan pembelajaran di masa pandemi ini. Guru dan siswa akan tetap aman berada pada tempat atau rumahnya masing-masing tanpa harus keluar rumah dan bertatap muka secara langsung. Namun, merubah pola atau kebiasaan sangatlah sulit, dan merupakan hal wajar ketika terjadi perubahan yang sangat cepat dan tidak terduga. Kebiasaan yang berubah secara signifikan ini misalnya, guru dan siswa sangat mengandalkan perangkat komputer dan jaringan internet, itu yang pertama (Andang, 2014).

Kedua, Guru dan siswa harus mampu merubah gaya, strategi atau metode mengajar dan belajar. Ketiga, guru dan siswa harus mampu merubah gaya komunikasinya selama pembelajaran daring ini. Banyak guru yang tidak memperhatikan bagiaan yang ketiga ini, yaitu kurangnya pemahaman dan penerapan guru dalam berkomunikasi dengan siswanya. Guru biasanya berkomunikasi satu atau dua arah di sekolah, dengan bertatap muka secara secara langsung melakukan diskusi dan latihan secara bersama-sama (Agustinus Hermino, 2014). Guru akan lebih mudah memberikan pemaparan dan penjelasan suatu materi, sedangkan siswa akan lebih mudah dalam memahami dan berdiskusi langsung kepada gurunya. Dengan kejadian pandemi ini, hal ini menjadi sangat sulit untuk tetap mempertahankan kebiasaan gaya komunikasi guru tersebut (Budi Suhardiman, 2012).

Komunikasi yang dipakai tentunya, yang bersifat jarak jauh dalam hal ini dikenal sebagai komunikasi daring. Komunikasi ini, memungkinkan guru sebagai komunikator dan siswa sebagai komunikan melakukan komunikasi melalui jaringan internet atau dunia maya (cyberspace) (Stolovith, 2007). Tujuannya ialah, bisa dikendalikan secara jarak jauh, efisiensi waktu jadi bisa dilakukan kapan saja dan dimana saja. Sangat mendukung kebijakan pemerintah dalam menaggulangi penyebaran pandemi ini. Di samping itu terdapat hal positif lainnya yang bisa didapatkan, seperti efisiensi biaya, sumber belajar yang luas, pengelolaan yang mudah, dan integrasi data. Namun, masih banyak yang belum menyadari kemudahan komunikasi daring ini. Ada 
dua jenis komukasi daring bisa dilakukan oleh guru dan siswa. Guru sebagai fasilitator informasi semestinya mampu membangun komunikasi daring yang efektif. Komunikasi yang efektif di sini adalah komunikasi yang senantiasa terjalin antara guru dan siswa sehingga nantinya dapat menimbukan perubahan sikap atau karater kearah yang lebih baik bagi siswa (Sedarmayanti, 2001).

Ketepatan informasi menjadi kunci dalam menciptakan komunikasi yang efektif. Hal ini terjadi jika persamaan pengertian, sikap, dan bahasa. Pesan atau informasi dapat diterima dan dimengerti serta dipahami sebagaimana yang dimaksud oleh komunikator (guru). Pesan yang disampaikan dapat disetujui oleh komunikan (siswa). Tidak adanya hambatan yang berarti dalam menndaklanjuti pesan atau informasi (Priansa, Donni Juni, 2014).

Ketiga hal tersebut adalah unsur terjadinya komunikasi yang efektif. Maka dari itu, untuk memenuhi unsur-unsur komunikasi efektif dalam pembelajaran daring ini, guru harus melakukan bebagai hal. Pertama, membuat aturan kelas daring, termasuk waktu dan aplikasi yang digunakan. Kedua, membangun suasana yang baik dalam berdiskusi dalam kelas daring, walaupun agak susah dilakukan namun usahakan siskusi dilakukan baik secara sinkron atau asinkron. Jangan sampai siswa yang bertanya atau membutuhkan penguatan tidak dilayani. Ketiga, walaupun dalam pembelajaran daring, guru semestinya tetap menggunakan ekpresi-ekpresi verbal maupun non-verbal dalam memberikan feedback, reward dan punishment. Bisa menggunakan emoticon, sticker, atau kalimat yang memotivasi siswa. Keempat, guru harus mampu mengaitkan materi dengan situasi terkini atau kekinian, sehingga akan mudah dipahami oleh siswa. Kelima, menggunakan video atau animasi yang yang mendukung materi sehingga tidak membosankan (Akdon, 2007).

Komunikasi perlu dibangun dengan memperhatikan beberapa hal seperti berikut. Pertama, menggunakan bahasa yang simple, yang mudah dipahami dan juga dapat memotivasi psikis siswa. Kedua, guru harus mampu memahami kondisi atau keadaan siswanya. Ketiga, makna dari pesan atau 
informasi haruslah jelas dan bermanfaat. Keempat, guru harus mampu menanamkan sifat respek dan saling menolong apabila ada siswa lain yang mengalami kesulitan.

Bisa saja dalam situasi ini siswa yang menolong guru dalam berbagai hal, misalnya kesulitan dalam menggunakan aplikasi. Kelima, guru juga harus menanamkan jiwa demokratis kepada siswanya. Demokratis ditunjukkan dengan memberikan kebebasan saling memberikan masukan selama pembelajaran daring, saling mendengar atau mengerti dengan keadaan dan mampu meberikan solusi dari setiap masalah yang dialami dalam pembelajaran daring saat pandemi Covid-19 ini. Ini juga memungkinkan penggunaan internet yang tinggi berpengaruh pada kesehatan peserta didik. Kendala lain yang ditemukan yakni kemampuan orang tua untuk memberikan fasilitas pendidikan online (Obiakor \& Adeniran, 2020) seperti penggunaan jaringan internet yang membutuhkan biaya (Purwanto et al., 2020).

Menurut Zhao (2003) Tinjauan literatur saat ini telah menemukan bahwa ada banyak penelitian tentang implementasi teknologi dalam pendidikan online berkaitan dengan penghematan biaya dan efisiensi, bahwa peningkatan kualitas dan efektivitas pendidikan online memerlukan kerangka kerja yang harus diterapkan di sekolah .Kerangka yang diusulkan memberikan panduan praktis kepada para pemangku kepentingan dalam penilaian kualitas pengajaran dan pembelajaran online (Stolovith, 2007). Menurut Chakraborty (2014) mengungkapkan beberapa faktor yang dapat menciptakan pengalaman belajar yang menarik bagi pembelajar online. Faktor utama adalah sebagai berikut: menciptakan dan memelihara lingkungan belajar yang positif; membangun komunitas belajar; memberikan umpan balik yang konsisten secara tepat waktu; dan menggunakan teknologi yang tepat untuk mengirimkan konten yang tepat.

Watkinds (2007) mengemukakan bahwa seiring dengan meningkatnya peluang pembelajaran online dalam masyarakat saat ini, pustakawan perlu mempertimbangkan cara-cara tambahan untuk merancang instruksi online secara efektif. Mengembangkan strategi yang diperlukan untuk mengajar dan belajar secara online dengan sukses membutuhkan pemahaman tentang gaya 
belajar dan bagaimana mereka dapat ditangani dengan baik di lingkungan online. Seperti halnya di kelas tatap muka, penggunaan gaya mengajar tertentu atau serangkaian gaya harus diperluas untuk mengatasi gaya belajar yang berbeda saat mengajar online. Pengajaran dan pembelajaran yang sukses tergantung pada semua peserta yang memiliki sikap yang diperlukan untuk berhasil di lingkungan online. Makalah ini memberikan informasi tentang gaya belajar dan mengajar, dan membahas bagaimana mengajar dengan berbagai gaya belajar dapat dilakukan dengan menggunakan alat dan sumber daya online yang tersedia. Asbari dkk, Pembelajaran pada Masa Pandemi Covid 19. Permasalahan tersebut tentu harus tetap di evaluasi guna memperoleh pembelajaran yang lebih baik. Kuncinya adalah untuk melakukan pembelajaran online sesaui dengan kondisi setempat (Zhang et al., 2020). Hal terpenting untuk menciptakan kemandirian dan keterampilan belajar peserta didik di tengah pandemic COVID-19.

\section{Kesimpulan}

Kompetensi guru dalam menggunakan teknologi akan mempengaruhi kualitas program belajar mengajar oleh karena itu sebelum diadakan program belajar online para guru wajib untuk diberikan pelatihan terlebih dahulu. Fasilitas ini sangat penting untuk kelancaran proses belajar mengajar, untuk pembelajaran online di rumahnya seharusnya disediakan dulu fasilitasnya seperti laptop, computer ataupun hand phone yang akan memudahkan guru untuk memberikan materi belajar mengajar secara online. Pembelajaran online memberikan kemudahan dalam memberikan transfer informasi pada berbagai situasi dan kondisi. Ragam manfaat dari kemudahan pembelajaran online didukung berbagai platform mulai dari diskusi hingga tatap muka secara virtual. Namun, hal ini perlu di evaluasi dan disesuaikan dengan kondisi setempat, mengingat kemampuan orang tua memberikan fasilitas pembelajaran online berbeda. Kuncinya adalah memaksimalkan kemampuan peserta didik belajar dalam kondisi pandemic seperti ini. 


\section{DAFTAR PUSTAKA}

Ahmadi, (1995), Kebutuhan Guru dan Tenaga Kependidikan Serta Peningkatan Mutu Pendidikan, Jakarta: Depdikbud.

Akdon. (2007), Strategic Management, for Educational Management, terj. Manajemen Strategik untuk Manajemen, Bandung: Alfabeta.

Andang, (2014), Manajemen dan Kepemimpinan kepala Sekolah: Konsep, Strategi dan Inovasi Menuju Sekolah Efektif, Yogyakarta: Ar-Ruzz Media.

Asbari. M.,Nurhayati. W.,Purwanto.A.. (2020).The effect of parenting style and genetic personality on children character development. Jurnal Penelitian dan Evaluasi Pendidikan: 23(2).

Budi Suhardiman, Studi Pengembangan Sekolah, (Jakarta: PT Rineka Cipta, 2012).

Chakraborty, M. and Muyia Nafukho, F. (2014), Strengthening student engagement: what do students want in online courses?", European Journal of Training and Development, Vol. 38 No. 9.

Firman, \& Rahayu, S. (2020). Pembelajaran Online di Tengah Pandemi Covid19. Indonesian Journal of Educational Science (IJES), 2(2), 81-89.

Gall, Meredith D., dkk, Educational Research, (New York, USA: Pearson Education Inc.)

Hermino, Agustinus, (2014), Kepemimpinan Pendidikan di Era Globalisasi, Yogyakarta: Pustaka Pelajar, h. 128-130.

Jean Rudduck dan David.Hopkins. Editors. Research as A Basis for Teaching Reading from The Work of Lawrence Stenhouse, (Oxford: Heinemann Educational Books, 1985), h. 116.

Khasanah, D. R. A. U., Pramudibyanto, H., \& Widuroyekti, B. (2020). Pendidikan Dalam Masa Pandemi Covid-19. Jurnal Sinestesia, 10(1), 41-48

Kusuma, J. W., \& Hamidah. (2020). Platform Whatsapp Group Dan Webinar Zoom Dalam Pembelajaran Jarak Jauh Pada Masa Pandemik Covid 19. Jurnal Ilmiah Pendidikan Matematika Volume, 5(1).

Obiakor, T., \& Adeniran, A. (2020). Covid-19 : Impending Situation Threatens To Deepen Nigeria'S Education Crisis. Center For The Study Of The Economies Of Africa.

Priansa, Donni Juni. (2014), Kinerja dan Profesionalisme Guru. Bandung: Alfabeta. 
Purwanto, A., Wijayanti, L.M., Hyun, C.C., Asbari, M. (2020). The Effects of Transformational, Transactional, authentic, Authoritarian Leadership style Toward Lecture Performance of Private University in Tangerang. Dinasti International Journal of Digital Business Management (DIJDBM), 1(1), 29- 42.

Sedarmayanti, Sumber Daya Manusia dan Produktivitas Kerja, (Bandung: Mandor Maju, 2001), h. 50.

Stolovith, Harold D. (2007), The Development and Evolution of Human Performance Improvement, Dalam Dempsey, John V. And Reiser, Robert A. Trends and Issues in Instructional Design and Technology, Second Edition, New Jersey: Pearson Merril Prentice Hall.

Watkinds, Ryan. Performance by Design: The Systematic Selection, Design, and Development of Performance Technologies that Produce Useful Results, (Massachusetts: HRD Press, Inc., 2007)

Wiranda, T., \& Adri, M. (2019). Rancang Bangun Aplikasi Modul Pembelajaran Teknologi WAN Berbasis Android. VoteTEKNIKA (Vocational Teknik Elektronika Dan Informatika), 7(4), 2302- 3295.

Zayapragassarazan, Z. (2020). COVID-19 : Strategies for Online Engagement of Remote Learners.

Zhang, W., Wang, Y., Yang, L., \& Wang, C. (2020). Suspending Classes Without Stopping Learning : China's Education Emergency Management Policy in the COVID-19 Outbreak. Risk and Financial Management.

Zhu, X., \& Liu, J. (2020). Education in and After Covid-19: Immediate Responses and LongTerm Visions.

Zhao, F. (2003), "Enhancing the quality of online higher education through measurement", Quality Assurance in Education, Vol. 11 No. 4. 